\title{
PERBANDINGAN DAYA SIMPAN DAN UJI ORGANOLEPTIK MIE BASAH DARI BERBAGAI MACAM BAHAN ALAMI
}

Ria Dwi Jayati ${ }^{*}$, Sepriyaningsih ${ }^{2}$, Silvia Agustina ${ }^{3}$

${ }^{123}$ STKIP PGRI Lubuklinggau, Jl. Mayor Toha Kel. Air Kuti, Lubuklinggau 31626, Indonesia

*Corresponding author, e-mail: ria2jayati@gmail.com

\section{ABSTRACT}

This study aims to determine the ratio of storability and organoleptic test of natural ingredients used to preserve wet noodles. The type of this research is qualitative descriptive research. The object of this research is wet noodles mixed with carrot juice, pampkin juice and turmeric juice. Data were collected through observation of shelf life for 8 days storage and organoleptic test against 50 panel of consumption panel. The result of the research shows that there is a comparison of storage power of each added juice. The conclusion of this research is the treatment with the longest shelf life that is for 8 day that is wet noodle which is added with carrot juice (P1), while for the fastest storage which is wet noodle is treatment P0 (control) for 1 day. The results of organoleptic test from wet noodles to the most acceptable power are wet noodles with the addition of pumpkin juice (P2).

Keywords: Storability, Organoleptic Test, Wet Noodles, Natural Ingredients

\section{PENDAHULUAN}

Industri pangan di Indonesia terus berkembang pesat, mulai dari skala kecil, menengah maupun besar, sehingga perlu dilakukan pengawasan terhadap produk yang dihasilkan. Salah satu industri pangan yang berkembang pesat di Indonesia adalah industri mie basah (Oktiarni, dkk., 2013). Mie basah merupakan jenis mie yang mengalami proses perebusan setelah tahap pemotongan dan sebelum dipasarkan. Mie basah di Indonesia dikenal sebagai mie kuning atau mie bakso. Mie basah memiliki cita rasa yang khas dan penyajiannya dapat dicampurkan dengan makanan lain, sehingga mie basah banyak disukai orang (Satyajaya \& Nawansih, 2008). Mie basah adalah jenis mie yang mengalami proses perebusan dengan kadar air mie basah matang mencapai 52\%, sehingga daya tahan atau keawetannya cukup singkat. Daya simpan mie basah yang cukup singkat menyebabkan banyak usaha untuk meningkatkan daya simpannya dengan menambahkan pengawet (Oktiarni, dkk., 2012).

Bahan pengawet merupakan bahan kimia yang berfungsi untuk memperlambat kerusakan makanan baik yang disebabkan mikroba pembusuk, (bakteri) dan jamur dengan cara menghambat, mencegah, menghentikan, proses pembusukan dan fermentasi dari bahan makanan (Dwiwati, 2014). Formalin dan boraks merupakan pengawet yang paling sering digunakan oleh pedagang-pedagang kecil untuk mengawetkan produk dagangannya tanpa menghiraukan keselamatan konsumen. Sementara itu, masyarakat tidak mampu memilih produk yang mengandung boraks dan formalin dengan produk tanpa boraks dan formalin karena sulit dibedakan secara fisik (Anwar \& Khomsan, 2009). 
Formalin adalah bahan pengawet yang biasa digunakan sebagai desinfektan, cairan pembalsem, pembasmi serangga dan untuk mengawetkan jaringan (Tangdiongga, dkk 2015). Masyarakat cenderung menggunakan dalam industri rumah tangga sebagai bahan pengawet makanan seperti pada pembuatan mie. Pemakaian bahan pengawet pada makanan dari satu sisi dapat menguntungkan produsen karena dengan adanya tambahan dari bahan pengawet ini makanan dapat terhindar dari mikroba sehingga mempunyai daya simpan lebih lama. Boraks atau asam borat biasa digunakan sebagai bahan pembuat detergen, bersifat antiseptik. Bahan berbahaya ini tidak boleh digunakan untuk makanan. Bahaya boraks jika terhirup, tertelan, mengenai kulit bisa menyebabkan iritasi saluran pernafasan, iritasi kulit, iritasi mata dan kerusakan ginjal. Jika boraks 5-10 gram tertelan oleh anak-anak bisa menyebabkan kematian (Indah, 2010). Namun disisi lain bahan pengawet tersebut apabila masuk ke dalam tubuh dapat menyebabkan berbagai masalah yang dapat mempengaruhi kesehatan (Habsah, 2012).

Gejala yang ditimbulkan jika formalin atau boraks tertelan yaitu mulut, tenggorokan dan perut terasa terbakar, sakit ketika menelan, mual, muntah, diare, kemungkinan terjadi pendarahan, sakit perut yang hebat, sakit kepala, hipotensi, kejang, tidak sadar hingga koma. Selain itu, formalin dan boraks bisa menyebabkan kerusakan hati, jantung, otak, limfa, pankreas, sistem susunan saraf pusat dan ginjal (Indah, 2010).

Mie basah mengandung formalin memiliki ciri-ciri yaitu tidak rusak sampai dua hari pada suhu kamar $\left(25^{\circ} \mathrm{C}\right)$ dan bertahan lebih dari 15 hari pada suhu lemari es $\left(10^{\circ} \mathrm{C}\right)$, tidak lengket dan mie lebih mengkilap dibandingkan mie normal, bau agak menyengat seperti bau formalin. Sedangkan ciri-ciri mie basah mengandung boraks yaitu teksturnya kenyal, lebih mengkilat, tidak lengket, dan tidak cepat putus (Indah, 2010).

Formalin dan boraks berbahaya bagi kesehatan, maka diperlukan alternatif pengawet makanan yang lebih aman dan sehat, salah satunya dengan menggunakan bahan-bahan alami. Beberapa jenis bahan alami seperti wortel, buah waluh dan kunyit dilaporkan memiliki aktivitas antimikroba yaitu senyawa yang dapat menghambat pertumbuhan mikroba sehingga makanan menjadi awet. Senyawasenyawa kurkumin dan minyak atsiri yang terkandung dalam kunyit mampu menghambat pertumbuhan bakteri, sehingga dapat mempertahankan mutu pangan. Senyawa kurkumin yang terkandung dalam kunyit sekitar 3 - 4\%. Semakin banyak kandungan senyawa kurkumin dan minyak atsiri dalam kunyit maka semakin lama pula daya tahan bahan makanan tersebut (Indonesian Food Teknologist, 2014). Pengawet alami juga bisa berasal dari wortel dan waluh karena terdapat betakaroten ( $\beta$-Karoten) atau provitamin A mempunyai fungsi antioksidan yang dapat menghambat atau memperlambat proses fermentasi (Dwiwati, 2014) sehingga dapat digunakan sebagai pengawet alami pada mie basah.

\section{METODE}

Penelitian ini menggunakan metode deskriptif, yaitu memanfaatkan jus wortel, jus waluh, dan jus kunyit terhadap mie basah. Analisis data secara deskriptif kualitatif yang meliputi uji daya simpan mie basah dan uji organoleptik. Percobaan dilakukan dengan 4 perlakuan, dengan $\mathrm{P} 0$ adalah kelompok kontrol (mie basah tanpa pengawet alami), P1 (mie basah dengan pengawet jus wortel), P2 (mie basah dengan pengawet jus waluh), P3 (mie basah dengan pengawet jus kunyit). Prosedur dalam penelitian ini dapat dilihat pada gambar 1. 


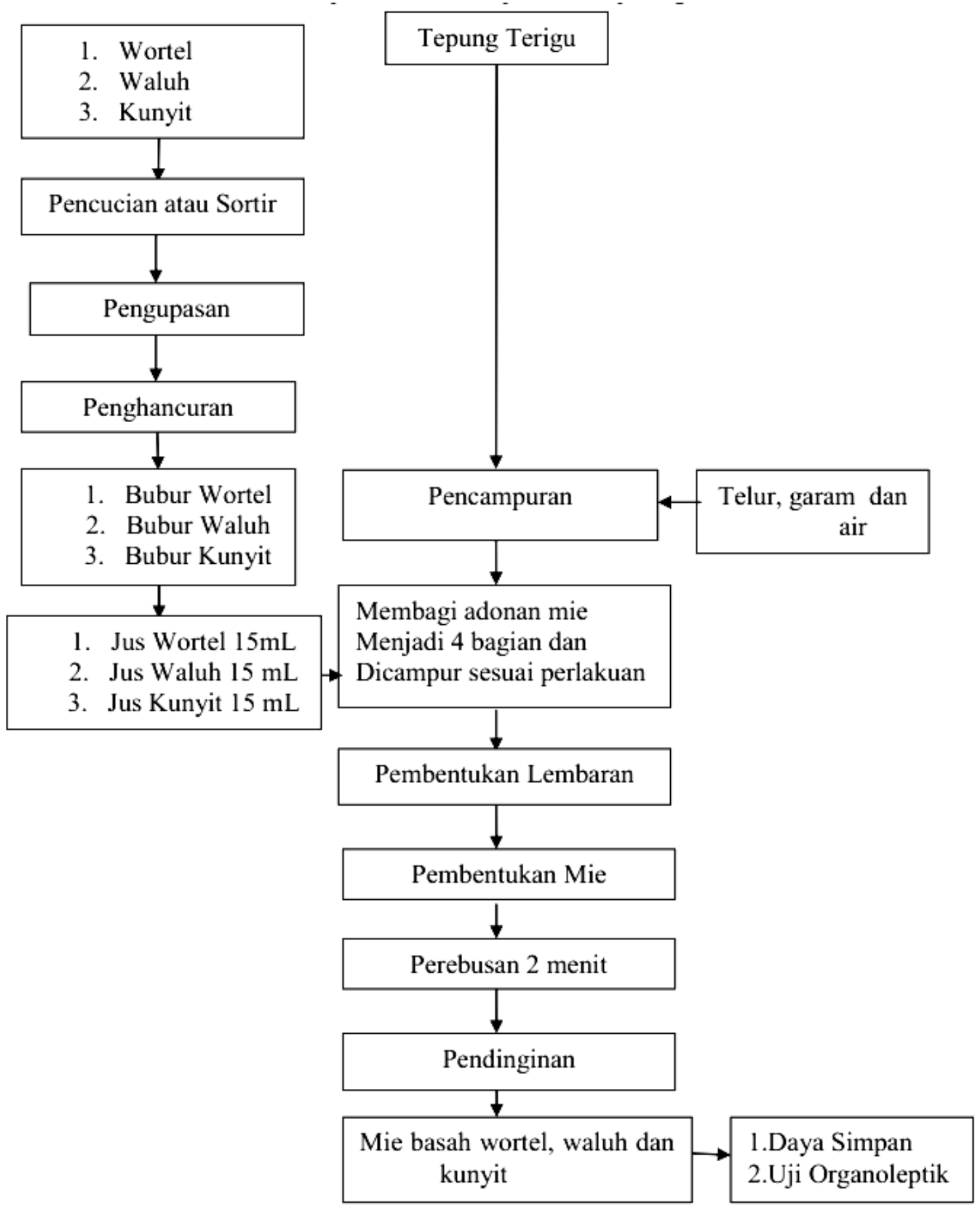

Gambar 1. Prosedur Penelitian

(Sumber: diadaptasi dari Nasution, dkk., 2006)

Uji daya simpan dilakukan dengan mengumpulkan data melalui penyimpanan mie basah dengan parameter suhu ruangan $\left( \pm 20-25^{\circ} \mathrm{C}\right)$ yaitu mie dimasukkan ke dalam plastik bening selama 8 hari. Data daya simpan yang diperoleh melalui lembar pengamatan. Data yang diperoleh dianalisis secara deskriptif kualitatif.

Uji organoleptik dilakukan dengan mengumpulkan data melalui pengukuran rasa, warna, aroma, tekstur dan daya terima yang dilakukan oleh 50 panelis konsumen dengan mengisi formulir yang sudah disediakan sebelumya setelah mendapatkan pengarahan dari peneliti. Data mutu fisik meliputi warna, tekstur, 
aroma dan rasa yang dikumpulkan melalui uji organoleptik oleh panelis, kemudian dianalisis secara deskriptif kualitatif.

\section{HASIL DAN PEMBAHASAN Daya Simpan}

Hasil pengamatan terhadap daya simpan pada mie basah pada masing-masing perlakuan disajikan dalam tabel 1. Daya simpan dilakukan dengan pengamatan setiap 12 jam sekali. Hasil penelitian yang dilakukan dapat dilihat pada tabel 1 yaitu hasil daya simpan mie basah dengan daya simpan terendah selama 1 hari yang terdapat pada perlakuan P0 (kontrol) dengan suhu ruangan $\left( \pm 20-25^{\circ} \mathrm{C}\right.$ ) dan mie basah dengan daya simpan tertinggi pada perlakuan P1 (wortel) selama 8 hari pada suhu ruang.

Tabel 1. Hasil Daya Simpan Mie Basah

\begin{tabular}{lll}
\hline No & Perlakuan & Rata-rata(hari) \\
\hline $\mathbf{1}$ & P0 (Kontrol) & 1 hari $\left({ }^{*}\right)$ \\
$\mathbf{2}$ & P1 (Wortel) & 8 hari $\left({ }^{* *}\right)$ \\
$\mathbf{3}$ & P2 (Waluh) & 6 hari \\
$\mathbf{4}$ & P3 (Kunyit) & 5 hari \\
\hline Keterangan: & \\
${ }^{* *}$ ) daya simpan tertinggi & \\
${ }^{*}$ ) daya simpan terendah
\end{tabular}

Mie basah P0 (kontrol) dalam penyimpan selama 12 jam sudah ada tandatanda pembusukan yaitu adanya jamur di permukaan mie. Daya simpan P0 rendah dikarenakan tidak adanya tambahan pengawet dalam adonan mie. Bakteri langsung menyerang mie basah sehingga mie basah dalam masa simpan 1 hari sudah mengalami pembusukan. Menurut Kurniawan, dkk (2015) bahwa daya tahan simpan mie basah relatif singkat yaitu 40 jam pada suhu kamar. Kerusakan mie basah biasanya ditandai dengan tumbuhnya kapang. Hal ini disebabkan oleh kadar air mie basah yang cukup tinggi yaitu 52\%. Tingginya kadar air pada mie basah matang disebabkan karena mie telah mengalami perebusan. Pertumbuhan kapang ditandai dengan adanya miselium kapang pada permukan mie. Miselium kapang pada mie umumnya berwarna putih atau hitam. Mikroba lain yang tumbuh pada mie adalah bakteri yang ditandai dengan terbentuknya lendir dan diikuti dengan timbulnya bau asam.

Daya simpan tertinggi yaitu selama 8 hari (192 jam) terdapat pada perlakuan P1 yang menggunakan jus wortel. Hal ini disebabkan wortel memiliki kandungan betakaroten yang mempunyai fungsi antioksidan yang dapat menghambat proses pertumbuhan bakteri. Menurut Oktiarni, dkk (2012) bakteri tidak langsung menyerang mie basah, tetapi menghancurkan betakaroten dengan kata lain menghambat oksidasi lemak lebih tepatnya peroksidasi lemak sehingga memperlambat kerusakan makanan. Menurut Dwiwati (2014) kandungan betakaroten wortel lebih besar yaitu 9,02mg/100g.

Daya simpan sedang pada perlakuan P2 (buah waluh) dan P3 (kunyit). Pada perlakuan P2 yaitu dengan menggunakan jus waluh, daya simpan selama 6 hari, buah waluh juga sama seperti wortel yaitu mengandung betakaroten sehingga bakteri tidak langsung menyerang mie basah, tetapi menghancurkan betakaroten dengan kata lain menghambat oksidasi lemak lebih tepatnya peroksidasi lemak sehingga memperlambat kerusakan makanan. Pada penelitian buah waluh sedikit kurang efektif dibandingkan dengan wortel, walaupun keduanya mempunyai kandungan 
betakaroten. Menurut Dwiwati (2014) kandungan betakaroten wortel lebih besar yaitu $9,02 \mathrm{mg} / 100 \mathrm{~g}$ dibandingkan pada buah waluh yang hanya mempunyai kandungan betakaroten 7,29mg/100g.

Pada perlakuan P3 dengan daya simpan selama 5 hari yaitu dengan menggunakan jus kunyit, di dalam kunyit terdapat senyawa kurkumin dan minyak atsiri yang merupakan kelompok persenyawaan fenolik dan golongan terpenoid. Menurut Pasaraeng (2013) kurkuminoid dan minyak atsiri menghambat metabolisme bakteri dengan cara merusak membran sitoplasma dan mendenaturasi protein sel yang menyebabkan kebocoran nutrisi dari sel sehingga sel bakteri mati atau terhambat pertumbuhannya.

Pengamatan mie basah dilakukan setiap 12 jam sekali dikarenakan pada perlakuan P0 (kontrol) saat 12 jam sudah ada tanda-tanda pembusukan yaitu dengan munculnya jamur dipermukaan mie. Dari hasil penelitian daya simpan mie basah, mie yang sudah mengalami pembusukan ditandai dengan adanya jamur di permukaan mie, berbau asam, berlendir dan tekstur mie menjadi lembut pada akhirnya bentuknya menjadi seperti bubur.

\section{Uji Organoleptik}

Uji organoleptik yang digunakan untuk mengetahui tingkat kesukaan dan penerimaan konsumen terhadap mie basah. Pengujian organoleptik ini dilakukan dengan menggunakan indra pembau, peraba, penglihatan dan perasa. Berdasarkan hasil uji organoleptik yang tertinggi disukai oleh masyarakat adalah mie basah dari buah waluh (P2) dan yang paling rendah adalah mie basah pada perlakuan P3 dengan penambahan jus kunyit.

Uji organoleptik dilakukan oleh 50 panelis konsumen dengan lokasi yang berbeda. Hasil organoleptik daya terima masyarakat secara umum menunjukkan bahwa warna mie basah kuning, aroma kurang menyengat, rasanya disukai oleh masyarakat, tekstur mie basah kenyal, dan daya terima masyarakat yaitu suka. Hasil nilai rata-rata yang tertinggi mie basah yang paling disukai atau diterima oleh masyarakat adalah mie basah dari buah waluh. Menurut Andriyani (2008) waluh memiliki rasa yang manis dan enak sehingga waluh sering digunakan dalam pembuatan produk makanan.

\section{Warna}

Hasil penilaian rata-rata uji organoleptik terhadap warna pada mie basah dapat dilihat gambar 2. Nilai rata-rata uji organoleptik tingkat warna terhadap mie basah menunjukkan nilai tertinggi 3,52 pada perlakuan P3 (kunyit) dengan kriteria kuning dan nilai terendah 1,12 pada perlakuan P0 (kontrol) dengan kriteria bukan kuning.

Warna memiliki peranan yang cukup penting dalam pangan. Selain bergizi, pangan harus memiliki warna yang menarik untuk dapat dikonsumsi. Mie basah umummya berwarna putih kekuningan. Warna ini disebabkan karena kandungan flavonoid yang terdapat pada tepung terigu (Oktiarni, dkk., 2012). Pigmen alami dapat terjadi pada bahan pangan yang belum diolah atau terbentuk selama proses pengolahan. Pigmen bahan pangan yang secara alami sering ditemui adalah karoteroid, klorofil, antosianin melanoidin dan mioglobin (Andarwulan, dkk., 2011).

Berdasarkan hasil uji organoleptik warna mie basah yang tertinggi pada perlakuan P3 (kunyit) dan warna mie basah yang terendah pada perlakuan P0 (kontrol). Pada perlakuan P0 (kontrol) mie basah berwarna putih kekuningan karena dalam adonan ada campuran tepung yang berwarna putih dan dari kuning telur. Pada 
perlakuan P3 yaitu mie dengan penambahan jus kunyit memiliki warna kuning lebih terang dibandingan dengan warna mie basah dari wortel dan buah waluh, karena didalam kunyit terdapat senyawa kurkuminoid. Kurkuminoid adalah senyawa yang berpartisipasi dalam pembentukan warna pada kunyit.

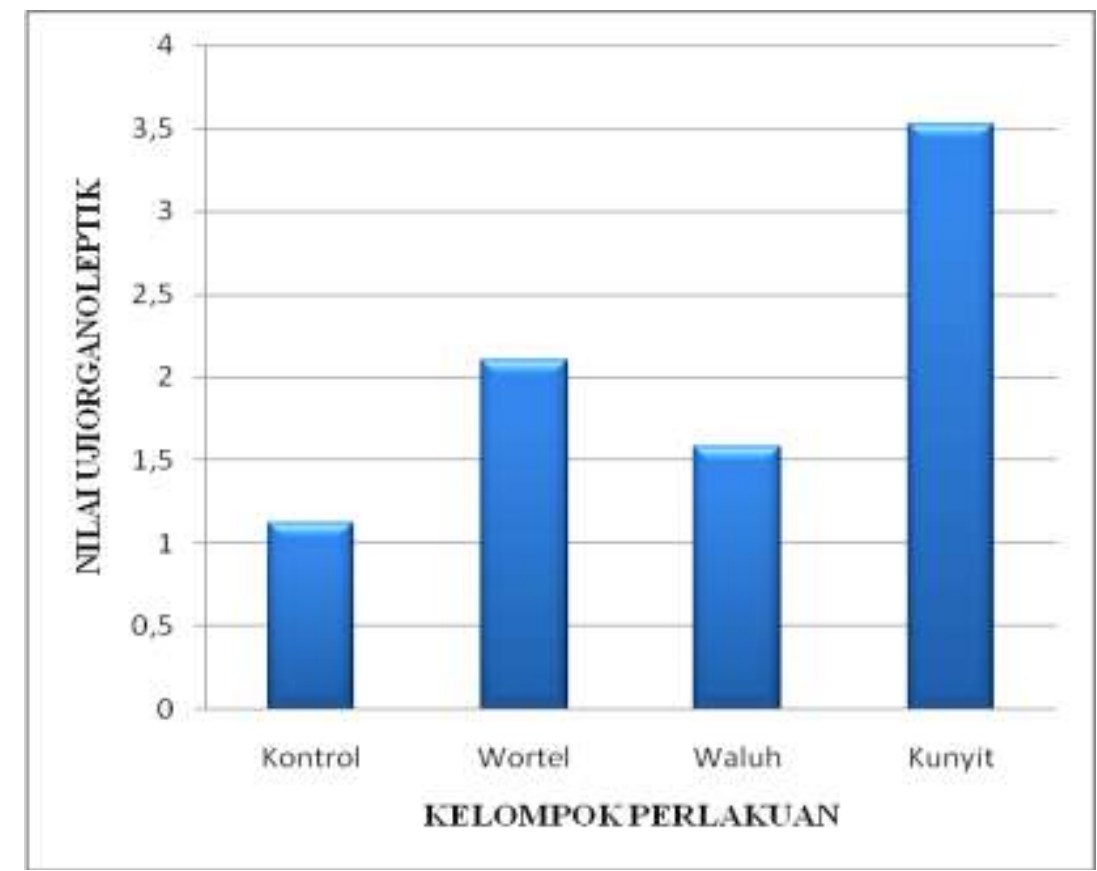

Gambar 2. Grafik Nilai Uji Organoleptik terhadap Warna Mie Basah

Mie basah dengan nilai organoleptik sedang pada perlakukan P1(wortel) dan P2 (waluh) memiliki warna kuning. Ini disebabkan karena adanya kandungan betakaroten (provitamin-A) yang terdapat pada wortel dan waluh sehingga menghasilkan warna kuning.

\section{Aroma}

Hasil penelitian rata-rata uji organoleptik terhadap aroma pada mie basah dapat dilihat dalam bentuk grafik pada gambar 3. Nilai rata-rata uji organoleptik tingkat aroma terhadap mie basah menunjukkan nilai tertinggi 2,14 pada perlakuan P3 (kunyit) dengan kriteria kurang menyengat dan nilai terendah 1,68 pada perlakuan P2 (buah waluh) dengan kriteria tidak menyengat.

Pengujian terhadap aroma dalam industri pangan dianggap penting karena dengan cepat dapat memberikan hasil penilaian terhadap produk tentang diterima atau tidaknya produk tersebut, karena aroma makanan menetukan kelezatan makanan tersebut. Aroma merupakan suatu yang dirasakan oleh hidung. Pada umumnya aroma yang diterima oleh hidung dan otak lebih banyak merupakan berbagai campuran dari empat bau utama yaitu harum, asam, tengik dan hangus serta menyengat atau tidak menyengatnya aroma tersebut (Oktiarni, dkk., 2013).

Berdasarkan hasil uji organoleptik aroma mie basah yang tertinggi pada perlakuan P3 (kunyit). P3 (kunyit) mempunyai aroma menyengat hal ini disebabkan kunyit memiliki kandungan minyak atsiri yang menentukan aroma kunyit. Pemakaian kunyit yang digunakan tidak begitu banyak menyebabkan aroma yang dihasilkan menyengat. Pada perlakuan P0 (kontrol), P1 (wortel) dan P2 (waluh) aroma mie basah tidak menyengat. Hal ini disebabkan penggunaan jus tidak begitu banyak, 
aroma jus wortel dan waluh tidak begitu kuat bahkan hampir tidak mempunyai aroma sehingga aroma yang dihasilkan tidak menyengat.

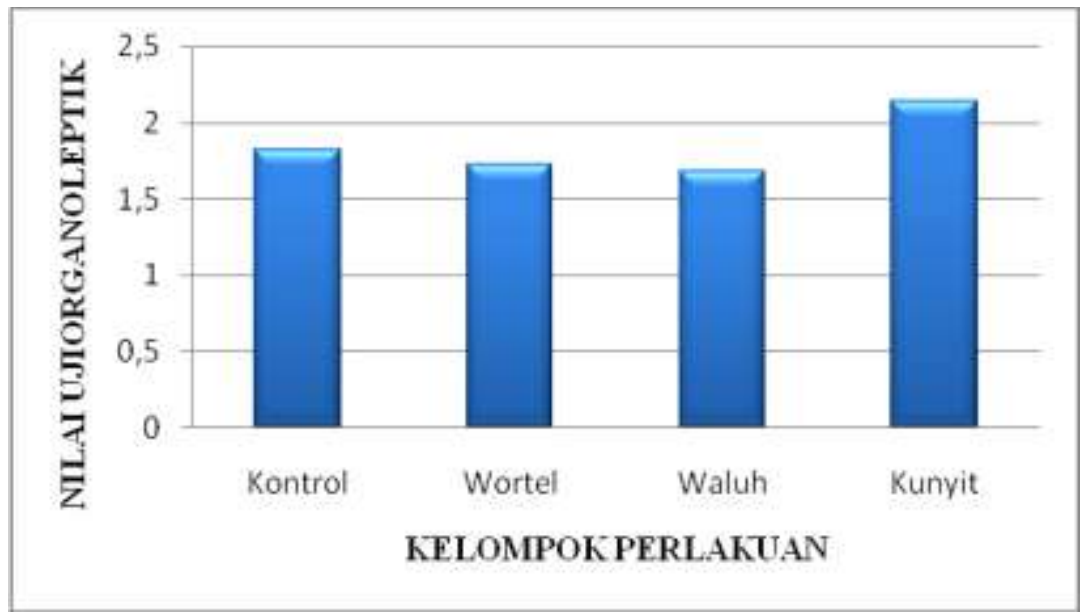

Gambar 3. Grafik Nilai Uji Organoleptik terhadap Aroma Mie basah

\section{Rasa}

Hasil penelitian rata-rata uji organoleptik terhadap rasa pada mie basah dapat dilihat pada gambar 4 .

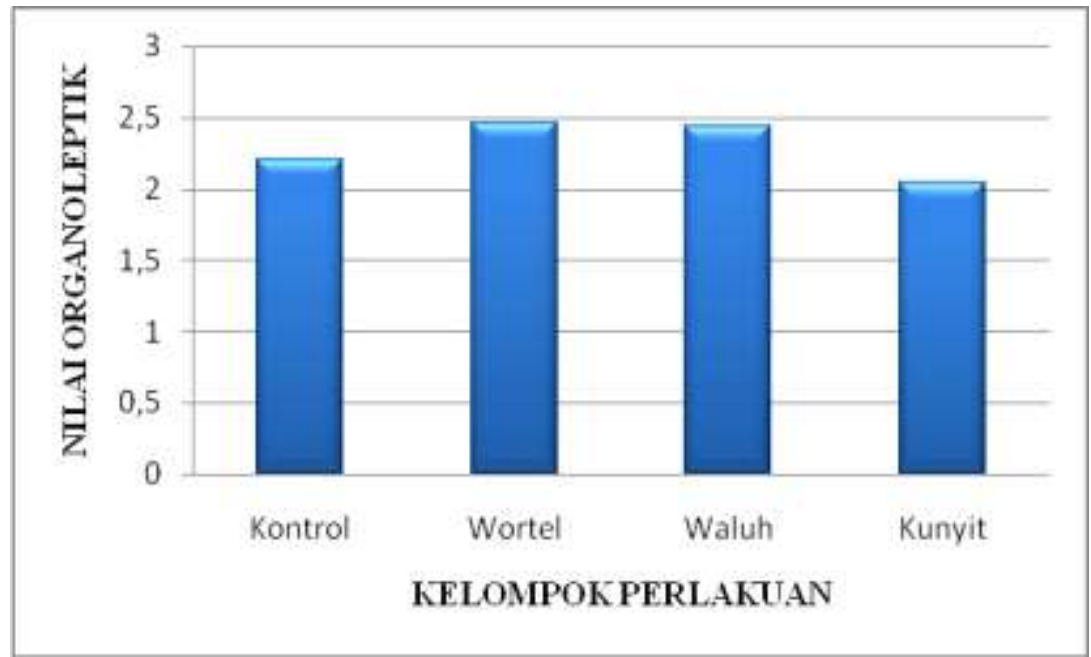

Gambar 4. Grafik Nilai Uji Organoleptik terhadap Rasa Mie Basah

Nilai rata-rata uji organoleptik tingkat rasa terhadap mie basah menunjukkan nilai tertinggi 2,46 pada perlakuan P1 (wortel) dengan kriteria suka dan nilai terendah 2,04 pada perlakuan P3 (kunyit) dengan kriteria suka.

Rasa lebih banyak melibatkan panca indra yaitu lidah, rasa juga merupakan sesuatu yang menjadikan makanan digemari oleh konsumen, karena dengan rasa maka konsumen dapat mengetahui dan menilai apakah makanan itu enak atau tidak. Rasa pada suatu makanan sangat lah dipengaruhi oleh bahan dasar yang digunakan (Kristianingsih, 2010).

Berdasarkan data uji organoleptik yang dilakukan oleh 50 orang panelis dari keempat sampel mie basah pada indikator rasa. Nilai uji organoleptik tertinggi pada perlakuan P1 dengan penambahan jus wortel sebanyak $15 \mathrm{~mL}$ dan nilai yang terendah yaitu P3 dengan penambahan jus kunyit sebanyak $15 \mathrm{~mL}$. 
Bahan-bahan pembuatan mie basah menggunakan telur, garam, dan bumbu dalam adonan. Pada perlakuan P1 dengan menambahkan jus wortel ke dalam campuran adonan mie basah sehingga ada rasa manis yang membuat rasa mie menjadi lebih disukai. Menurut Pracaya (2009) rasa manis pada wortel karena mengandung zat gula menyebabkan wortel disukai banyak orang. Nilai terendah pada uji organoleptik rasa terdapat pada perlakuan P3 dengan menggunakan jus kunyit. Hal ini disebabkan rasa kunyit sedikit getir yang ditimbulkan oleh adanya minyak atsiri.

\section{Tekstur}

Hasil penelitian rata-rata uji organoleptik terhadap tekstur pada mie basah dapat dilihat pada gambar 5. Nilai rata-rata uji organoleptik tingkat tekstur terhadap mie basah menunjukkan nilai tertinggi 2,5 pada perlakuan P1 (wortel) dengan kriteria kenyal dan nilai terendah 2,2 pada perlakuan P0 (kontrol) dengan kriteria kenyal.

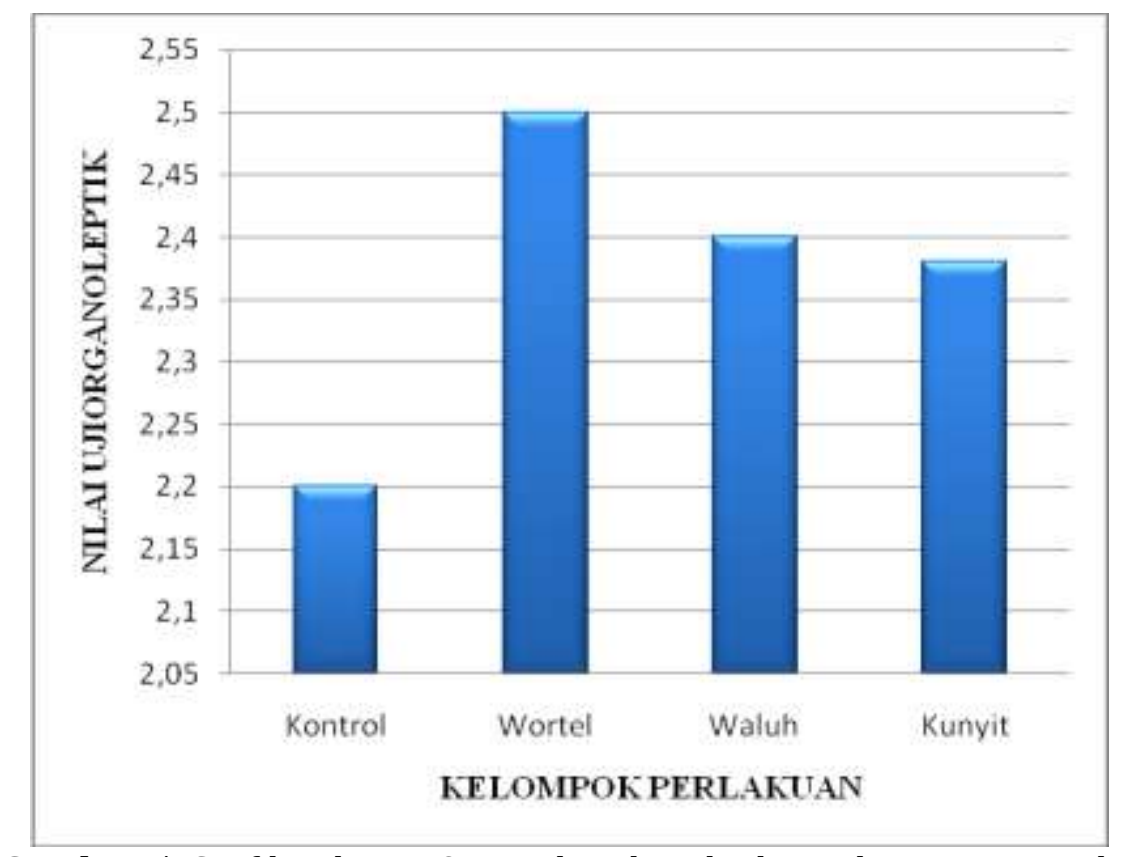

Gambar 5. Grafik Nilai Uji Organoleptik terhadap Tekstur Mie Basah

Mie basah diharapkan memiliki tekstur yang lembut dan kenyal. Tekstur mie basah berkaitan dengan protein yang berada pada bahan baku tepung terigu. Tepung terigu yang digunakan mengandung $14 \%$ protein. Semakin tinggi protein pada tepung terigu, maka semakin baik tekstur mie basah yang dihasilkan, dimana penyerapan air semakin besar sehingga menurunkan tingkat kekerasan. Banyaknya kandungan air di adonan membuat mie menjadi lembek sedangkan air yang sedikit membuat adonan menjadi keras (Billina, dkk., 2014).

Berdasarkan hasil uji organoleptik 50 orang panelis menunjukkan bahwa mie basah memiliki tekstur kenyal. Tingkat kekenyalan tertinggi mie basah terdapat pada perlakuan P1 (wortel) sedangkan tingkat kekenyalan terendah terdapat pada perlakuan P0 (kontrol). Pada perlakuan P1 (wortel) menghasilkan tekstur yang kenyal. Menurut Harahap (2009) bubur wortel memiliki kandungan abu, mineral kalsium (Ca) dan kalium (K), soda abu berfungsi untuk mempercepat pengikatan 
gluten, elastisitas fleksibilitas mie, sehingga meningkatkan teksture dan kekeknyalan mie.

Tingkat kekenyalan terendah pada perlakuan P0 (kontrol) disebabkan pada proses perebusan mie basah kontrol terlalu matang sehingga menyebabkan tekstur mie menjadi lembut dan kurang kenyal. Mie dimasak dengan waktu perebusan yang singkat, waktu perebusan yang lama akan menjadkan mie lembek karena ada air yang masuk ke dalam mie (Kurniawan, dkk., 2015).

Tingkat kekenyalan pada mie tergantung dari banyaknya tepung terigu yang digunakan. Tepung terigu memiliki kandungan gluten yang lebih tinggi, gluten adalah zat yang hanya terdapat pada tepung terigu. Sifat dari zat ini adalah kenyal dan elastis. Kekenyalan pada mie merupakan faktor utama yang dapat mempengaruhi kualitas mie. Mie dapat dikatakan baik apabila memiliki tekstur yang kenyal dan tidak terputus-putus. Faktor lain yang mempengaruhi tekstur pada mie adalah saat proses perebusan, mie direbus selama 2 menit pada air mendidih, tanda mie yang telah masak akan mengapung. Apabila mie terlalu lama dimasak menyebabkan mie menjadi lembek.

\section{Daya Terima}

Hasil penelitian rata-rata uji organoleptik terhadap daya terima pada mie basah dapat dilihat pada gambar 6 .

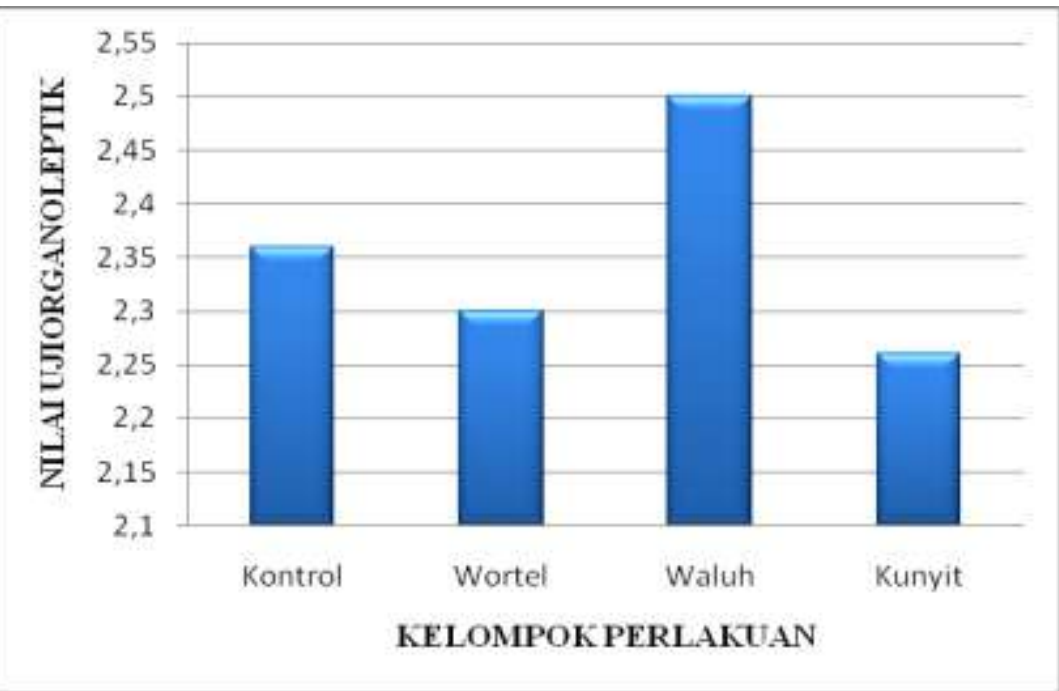

Gambar 6. Grafik Nilai Uji Organoleptik terhadap Daya Terima Mie Basah

Nilai rata-rata uji organoleptik tingkat daya terima terhadap mie basah menunjukkan nilai tertinggi 2,5 pada perlakuan P2 (waluh) dengan kriteria suka dan nilai terendah 2,26 pada perlakuan P3 (waluh) dengan kriteria suka.

Hasil uji organoleptik terhadap daya terima masyarakat pada semua perlakuan mie basah adalah suka. Hal ini menunjukan bahwa dengan penambahan jus wortel, waluh dan kunyit tidak mempengaruhi minat masyarakat untuk mengkonsumsi mie basah. Daya terima masyarakat di pengaruhi oleh warna, aroma, rasa dan tekstur dari mie basah.

Berdasarkan hasil uji organoleptik daya terima mie basah yang tertinggi pada perlakuan P2 (waluh) dan daya terima terendah pada perlakuan P3 (kunyit). Pada perlakuan P2 dengan penambahan jus waluh ke dalam adonan mie basah menyebabkan ada rasa manis pada mie basah. Rasa manis pada waluh karena 
mengandung zat gula menyebabkan waluh disukai banyak orang. Menurut Andriyani (2008) waluh memiliki rasa yang manis dan enak sehingga waluh sering digunakan dalam pembuatan produk makanan.

Nilai terendah pada uji organoleptik daya terima terdapat pada perlakuan P3 dengan menggunakan jus kunyit, hal ini disebabkan rasa kunyit sedikit getir yang ditimbulkan oleh adanya minyak atsiri serta aroma kunyit yang menyengat kurang disukai oleh panelis.

Panelis didominasi oleh suku Palembang, Jawa dan Melayu, hal ini dikarenakan banyak suku Palembang, Jawa dan Melayu di Lubuklinggau. Masyarakat sering mengkonsumsi mie dengan berbagai jenis mie, seperti mie ayam, mie jawa, mie tumis dan mie goreng, sehingga mie yang terbuat dari jus wortel, waluh dan kunyit dapat diterima oleh panelis baik dari segi warna, aroma, rasa dan tekstur.

\section{SIMPULAN}

Berdasarkan hasil penelitian mengenai perbandingan daya simpan dan uji organoleptik jus wortel, waluh dan kunyit dalam pembuatan mie basah dapat disimpulkan bahwa, daya simpan mie basah yang paling lama pada perlakuan P1 selama 8 hari (192 jam) dengan menggunakan jus wortel sebanyak 15 mL pada suhu ruang dan mie basah dengan daya simpan paling cepat pada perlakuan P0 (kontrol) selama 1 hari (24 jam). Hasil uji organoleptik mie basah yang paling disukai yaitu mie basah P2 dengan tambahan jus waluh sedangkan yang paling rendah yaitu mie basah P3 dengan jus kunyit.

\section{REFERENSI}

Andarwulan, N., F. Kusnandar \& D. Herawati. (2011). Analisa Pangan. Jakarta: Dian Rakyat.

Andriyani. (2008). Pengaruh Jumlah Bubur Labu Kuning dan Konsentrasi Kitosan Terhadap Mutu Mie Basah, (Skripsi). Medan: Universitas Sumatera Utara.

Anwar, F. \& Khomsan, A. (2009). Makan Tepat Badan Sehat. Jakarta: PT. Mizan Publika.

Billina, A., S. Waluyo \& D. Suhandy. (2014). Kajian Sifat Fisik Mie Basah dengan Penambahan Rumput Laut. Jurnal Teknik Pertanian Lampung, 4 (2), 109-116.

Dwiwati, R. (2014). Pemanfaatan Ekstrak Wortel (Daucus carota) dan Buah Waluh (Cucurbita moschata) Sebagai Bahan Pengawet Alami Bakso Daging, (Skripsi). Surakarta: Universitas Muhammadiyah.

Habsah. (2012). Gambaran Pengetahuan Pedagang Mie Basah Terhadap Perilaku Penambahan Boraks dan Formalin Pada Mie Basah di Kantin-kantin, (Skripsi). Jakarta: Universitas Depok.

Harahap, N. A. (2009). Pembuatan Mie Basah dengan Penambahan Wortel (Daucus carota L.), (Skripsi). Sumatera Utara: Universitas Sumatera Utara.

Indah, SY. (2010). Kitab Ekstrem Kuliner. Surabaya: PT. Java Pustaka Media Utama.

Indonesian Food Teknologist. (2014). Potensi Kunyit Sebagai Pengawet Alami Pada Produk Pangan. Retrieved from http://www.ift.or.id/2014/01/potensi-kunyitsebagai-pengawet-alami.html.

Kristianingsih, Z. (2010). Pengaruh Substitusi Labu Kuning Terhadap Kualitas Brownies Kukus, (Skripsi). Jakarta: Universitas Negeri Semarang.

Kurniawan, A., Estiasih T., \& Nugrahini N. I. P. (2015). Mie Dari Umbi Garut (Maranta arundinacea L.). Jurnal Pangan dan Agroindustri, 3(3), 847-854. 
Nasution, Z, T. Bakkara dan M. Manalu. (2006). Pemanfaatan Wortel (Daucus carota) Dalam Pembuatan Mie Basah Serta Analisa Mutu Fisik dan Mutu Gizinya. Jurnal Ilmiah PANNMED, 1(1), 9-13.

Oktiarni, D, D. Ratnawati \& D. Z. Anggraini. (2012). Pemanfaatan Ekstrak Buah Naga Merah (Hylocereus polyhizus sp.) Sebagai Pewarna dan Pengawet Alami Mie Basah. Jurnal Gradien, 8(2), 819-824.

Oktiarni, D., D. Ratnawati \& B. Sari. (2013). Pemanfaatan Ekstrak Bunga Kembang Sepatu (Hibiscus rosa sinensis Linn) sebagai Pewarna Alami dan Pengawet Alami Pada Mie Basah. Prosiding Seminar Semirata FMIPA BKS Barat, 1(1), 103-109.

Pasaraeng, E. (2013). Pemanfaatan Rimpang Kunyit (Curcuma domestica Val) Dalam Upaya Mempertahankan Mutu Ikan Layang (Decapterus sp), (Skripsi). Manado: FMIPA UNSRAT.

Pracaya. (2009). Bertanam Sayur Organik. Jakarta: Penebar Swadaya.

Satyajaya, W. \& Nawansih, O. (2008). Pengaruh Konsentrasi Chitosan Sebagai Bahan Pengawet Terhadap Masa Simpan Mie Basah. Jurnal Teknologi dan Industri Hasil Pertanian, 13(1), 17-24.

Tangdiongga, R.R., L.C., Mandey \& F. Lumoindong. (2015). Kajian Analisis Kimia Formaldehida dalam Peralatan Makan Melamin secara Spektofotometri Sinar Tampak. Jurnal Ilmu dan Teknologi Pangan, 3(1), 1-6. 